\title{
Harnessing a records management programme for justice delivery at the Alice magistrate court in the Eastern Cape Province, South Africa
}

\author{
Khunjulwa Ntengenyane \\ University of Fort Hare \\ nkhunjulwa@gmail.com
}

\author{
Festus Khayundi \\ University of Fort Hare \\ fkhayundi@ufh.ac.za
}

Received: 24 February 2021

Revised: 05 April 2021

Accepted: 29 August 2021

\begin{abstract}
This article focuses on harnessing a records management programme for justice delivery at the Alice Magistrates' court. The objectives of the study were to find the extent to which court records are managed for justice delivery, the influence of court records in court processes, and the challenges, if any, of managing court records for justice delivery. The population of the study comprised all those who created and used court records at the Alice Magistrates' court. The study used both quantitative and qualitative methods for data collection. Quantitative data were coded and analysed using Microsoft Excel 2010 while qualitative data were analysed using emerging themes based on the objectives of the study. The findings revealed that although records were important for justice delivery by the court, there were challenges posed by inadequate infrastructure, the lack of necessary knowledge and skills, ineffective control of records for justice delivery, and inadequate facilities for preservation and security of records. The study recommended improvement of the existing records management programme as a strategy. This is necessary for effective and efficient records management programme for justice delivery by the Alice Magistrates' court.
\end{abstract}

Keywords: Court records management, justice delivery, Alice Magistrate Court, Eastern Cape Province, South Africa

\section{Introduction}

Records are important for the success of justice delivery by courts. Records support judicial decision-making, documentation of legal rights, public access to court proceedings and decisions, enforcement of court orders and judgements, preservation of records for appellate review, and preservation of historical information (Abioye 2014; Dewah \& Mutula 2016; Raaen 2014). Records used as evidence must conform to applicable policies, legislation, regulations, standards, codes of practice, procedures and community expectations (ISO 154891 2016; Kilgour 2013; Lowry 2013). A records management programme ensures efficient and systematic control of creation, receipt, maintenance and use, and disposition by capturing and maintaining evidence of and information about the business activities and transactions (ISO 15489-1 2016:3). This provides information that guarantees unbiased and transparent justice delivery free from corruption, protracted case hearings and convictions (South Africa Law Commission 2002). It also upholds the credibility of the judicial system as well as the rights of 
individuals and society at large (Dewah \& Mutula 2016; Motsaathebe \& Mnjama 2009; Ngoepe \& Makhubela 2015).

Records management programmes in sub-Saharan Africa (SSA) generally are weak due to archaic legal frameworks, a lack of the necessary equipment, infrastructure, and personnel with the necessary knowledge and skills. Although legislative frameworks for records management programmes exist, many records management programmes are weak, while others have simply collapsed (Abioye 2014; Lowry 2013; Ngoepe 2016). Junior staff or people with no knowledge of records management such as police and prosecutors are responsible for managing court records (Ngoepe \& Makhubela 2015). Moreover, court registries function with poor infrastructure and lack the necessary records management resources. This results in backlogs, misplacement and loss of records. This has adverse effect on justice delivery, including delayed justice delivery or justice denied (Huni \& Dewah 2019; Ngoepe \& Makhubela 2015; South Africa Law Commission 2002).

The adoption of ICT/e-government and freedom of information initiatives by governments is a welcome relief to managing of court records. Electronic records management systems keep records and other information safe for accuracy and reference (Caughey 2004). However, courts are curious about the authenticity of digital records. Admissibility of digital records as evidence in court should comply with relevant local criminal and civil evidence law (Huni \& Dewah 2019). Many countries have are or in the process of reviewing and enacting legislation to stipulate requirements for admissibility of digital records as evidence in court (Huni \& Dewah 2019; Government of South Africa 2002; Lowry 2013; Saurombe 2014). According to Huni and Dewah (2019), current laws on Criminal and Civil Evidence in Zimbabwe remain silent on admissibility of digital records as evidence in court but there is hope that the proposed Computer Crime and Cyber Bill will provide for admissibility of digital records as evidence in courts. In South Africa, the Electronic Communications and Transaction Act (Act no. 25 of 2002), legalises electronic communications and transactions (Government of South Africa 2007).

\section{Background}

The South African Constitution recognises the judiciary as the judicial arm of government. It operates under the national Department of Justice and Constitutional Development (DOJ\&CD). The judiciary comprises the Constitutional Court, the Supreme Court of Appeal, the high courts, the magistrates' courts, and any other court established in terms of an Act of Parliament, including any court of a status similar to either the high courts or the magistrates' courts (Constitution of the Republic of South Africa No. 108 of 1996 as amended 2003).

The magistrates' courts form the first line of justice delivery. They only deal with less serious criminal and civil cases (Judicial System of South African Government 2021; Meintjes-Van der Walt et al. 2011). There are more than 400 magistrates' courts, subdivided into regional magistrates' courts and district magistrates' courts. Alice Magistrates' Court is a district magistrate court and it deals with both criminal and civil cases.

A project by the International Records Management Trust (IRMT) and the World Bank, established that court records management programmes in Africa, including South Africa, were 
unviable (IRMT 2002). Moreover, a study by the United Nations on South African courts indicated that there was widespread perception of corruption, undue delays, and inexperienced judicial officers taking place across the country (Ngoepe \& Makhubela 2015). Apparently, there was a remarkable transformation in the management of records and archives after 1994. There are many legislative and statutory requirements to provide a framework for managing records and archives including, among others:

- The Constitution, 1996

- The National Archives and Records Service of South Africa Act (NARSSA Act) (Act no. 43, 1996 as amended),

- The National Archives and Records Service of South Africa Regulations (R158 of 20 November 2002)

- The Promotion of Access to Information Act (PAIA) (Act no. 2 of 2000),

- The Promotion of Administrative Justice Act (PAJA) (Act no. 3 of 2000),

- The Electronic Communications and Transactions Act (ECTA) (Act no. 25 of 2002),

- The Public Finance Management Act (PFMA) (Act no. 1 of 1999).

- The Protection Of Personal Information Act (POPIA) (Act no. 4 of 2013)

The NARSSA Act (Act no. 43 of 1996) as amended) is the umbrella for records and archives management at national level while the respective provincial archives and records legislation underpins management of provincial records and archives. The national or provincial archivist monitors records management programmes to ensure management of records throughout the lifecycle. Additionally, court records management must ensure admissibility records as evidence according (Criminal Procedures Act (Act no. 51 of 1977) and section 35(5) of the Constitution of South Africa (Meintjes-Van der Walt et al. 2011).

\section{Statement of the problem}

Justice delivery is a major function of any judicial system. More importantly, delivery of justice cannot be separated from records. Records are critical to justice delivery because they support judicial decision-making, documentation of legal rights, public access to court proceedings and decisions, enforcement of court orders and judgements, preservation of records for appellate review, and preservation of historical information (Abioye 2014; Dewah \& Mutula 2016; Kilgour 2013; Lowry 2013). There is a strong relationship between records management and justice delivery. On the one hand, records management programmes guarantee admissibility of records as evidence for justice delivery. On the other hand, poor records management results in justice delayed or denied. Justice delayed or denied results in subversion of the justice delivery system. This undermines the credibility of the justice delivery system as well as the rights of individuals and society (Dewah \& Mutula 2016; Motsaathebe \& Mnjama 2009; Ngoepe \& Makhubela 2015; Ngoepe, Mokoena \& Ngulube 2010). Mass media, empirical and content analysis studies, and reports have highlighted the effect of poor records management on justice delivery by courts in South Africa (IRMT 2002; Ngoepe \& Makhubela 2015; Samodien 2013; South Africa Law Commission 2002). Unfortunately, there are relatively few empirical studies on records management for justice delivery in South Africa (Mafu 2014; Ntengenyane 2018). 


\section{Purpose of the study}

The purpose of this study was to examine the harnessing of a records management programme for justice delivery at the Alice Magistrates' Court in the Eastern Cape Province, South Africa.

\section{Objectives of the study}

The specific objectives of the study were to:

- find the extent of a records management programme justice delivery in the Alice Magistrates' Court

- determine the importance of records in the delivery of justice by the Alice Magistrates' Court

- find what challenges managing court records for justice delivery in Alice Magistrates' Court faced.

\section{Methodology}

The study adopted a mixed methods approach. This enabled the researcher to understand the respondents' views, opinions, and knowledge about court records management at the Alice Magistrates' Court (Leedy \& Ormrod 2010). The purposive sampling technique was used to select respondents as the researcher sought to target those with relevant knowledge of the phenomenon under study. Quantitative and qualitative data were collected using questionnaires, observation, and in-depth interviews. The population of the study included court staff who provide services and use records at the Alice Magistrates' Court. Therefore, the total population of the study included one magistrate, one court manager, and seven court clerks. The population was selected using purposive sampling. Data were analysed using emerging themes based on the research objectives. In this study, the researcher briefed the participants about this research before they started answering the questions. The participants were assured about confidentially to protect the privacy of their names and any other information that would identify their identity. As a result, the researcher used names to identify the participants in the study, thus maintaining their anonymity. Moreover, participants were informed that their participation was voluntary and they were free to withdraw from the study at any time.

\section{Findings and discussion}

The section discusses the findings according to the objectives that guided the study.

\subsection{Management of court records in the Alice Magistrate Court}

Implementation of records management programmes in government departments and institutions should comply with the requirements of the NARSSA Act and respective provincial archives and records service legislation. Accordingly, records management by government bodies must:

- develop classification systems that are approved by the national/ provincial archives

- obtain disposal authorities on all records from the national/provincial archives

- implement electronic records systems that are determined by the national/provincial archives 
- care for public records as required or prescribed by the national/provincial archives

- appoint or designate senior officials as records managers (Ngoepe 2016:341).

Although the provisions have been in existence for over two decades, implementation remains long forthcoming as government bodies design records management programmes without taking models appropriate for implementation into consideration (Ngoepe 2016:339). The purpose of this objective was to determine the extent of a records management programme at the Alice Magistrates' Court as it pertains to records creation/receipt, classification systems, retrieval and use, file plan/disposal authority, storage and security, and human capital.

The findings at the Alice Magistrates' Court indicated that records resulted from activities and transactions between the court and stakeholders as confirmed by $57 \%$ of the respondents. Previous studies of court registries elsewhere in the Eastern and Southern Africa reported registries as major sources of records creation and management (Lowry 2013; Luyombya \& Sennabulya 2012; Motsaathebe \& Mnjama 2009).

Furthermore, during case hearings, magistrates or judges make notes that eventually become part of the records (docket) for each case. Moreover, this researcher observed that, during court sessions, the magistrate used the charge sheet and the criminal record book to record presentations from the prosecutor and other stakeholders for each case. In addition, court sessions were audio-recorded hence became part of records in justice delivery. These are important sources of records creation.

The majority of the respondents indicated the use of a numerical classification system and only a few the use of an alphanumeric classification system in the organisation. Mafu (2014) reported the use of numerical and chronological classification systems in the Middledrift Magistrates' Court. Records classification systems organise files and documents into logical order to facilitate controlled access and disposal (ISO 15489-2016; Government of South Africa 2007). Equally, records classification systems are crucial in the retrieval of records to enable government departments and institutions to provide efficient services to the public and support the business, legal and accountability requirements of government bodies and organisations (Government of South Africa 2007). Classification systems have to ensure that all members of an organisation are filing records in the same way and are using common terminology (Barroca 2014). In terms of section 13(2)(b)(i) of the NARSSA Act, as amended, the national archivist or the representative of the national archivist determines the records classification systems applied in governmental bodies.

Furthermore, a classification system is necessary for the compilation of file plans or record schedule authorities. According to NARSA, the compilation of file plans and records disposal schedules takes place under the direction and approval of the national archivist. Although the majority (five out of seven (71\%)) of the respondents indicated their knowledge of a file plan and records disposal schedules, there was no evidence of file plans or records disposal schedules at the Alice Magistrates' Court. This pointed to a possible lack of capacity to compile and implement these tools. According to the NARSA Records Management Policy Manual (2007), records management programme managers must ensure training for all registry staff in file plan and maintenance procedures. File plans and records disposal schedules play a crucial role in managing records through the lifecycle. Record disposal schedules authority guards 
against unauthorised disposal or destruction of records. According to PAJA, unauthorised destruction could be considered a deliberate action to conceal the reasons for administrative action. Therefore, records management programmes should minimise the risks of not managing their records properly against the risk of being held accountable for administrative action (Government of South Africa 2007). Incidents of miscarriage and subversion of justice have been reported in the mass media and studies (Ngoepe \& Makhubela 2015; Samodien 2013).

The adoption of information and telecommunication technologies (ICTs) revolutionised the creation, storage, and dissemination of information. In many countries, electronic records management systems in courts ensure protection of the authenticity, reliability, integrity and usability of records (ISO 15489-1 2016). Moreover, this makes information quickly and conveniently accessible online. Electronic filing systems, make it easier, for instance, for journalists, lawyers or ombudsmen fully understand what is happening in any particular case within the system (Spratt 2007). In Botswana, the Department of the Administration of Justice (AOJ) adopted the Court Records Management System (CRMS) to manage case files. The system is used as a tool for recording and keeping all files and other information safe for accurate and quick reference (Mosweu \& Kenosi 2018). According to Maseh (2015), the judiciary in Kenya recently digitised court records, which streamlined the management of records for easy and timeous retrieval.

The South African Department of Justice and Constitutional Development developed e-justice systems for the judiciary (Saurombe 2014; Sindane 2013). Electronic records management programmes for justice delivery requires compliance with legislative and statutory requirements as well as national and international standards for management of digital records. In addition, there is a need for ICT infrastructure and human capital (Ambira, Kemoni \& Ngulube 2019; Lowry 2013; Ngoepe 2016). Although the manager indicated that the court implemented an e-justice system, the researcher did not feel that there was not active creation and management of electronic records at the Alice Magistrates' Court. The majority of the respondents indicated that the court had access to electronic records in the Middledrift Magistrates' Court. The court manager confirmed this saying that:

There are challenges and complaints on the physical side of the record, because there is misfiling, before we had these computers, it was easy to steal a file, it was easy to misfile a file in these cabinets and sometimes on this file, there is this disposal instruction or directions as to disposal.

The researcher was interested in the preservation, storage and security of court records. This is important because records, regardless of format or media, should be stored in a way that protects them from unauthorised access, change, loss or destruction, including theft and disaster (ISO 15489-1 2016). The responses indicated that five out of seven (71\%) of the respondents indicated storage of records in cabinets and strong room, while two out of seven $(29 \%)$ mentioned the registry. However, the researcher observed some records kept in the offices of the court manager and the prosecutor. This definitely posed a risk to preservation and security of the court records. It was not surprising there were incidences of missing or misplaced records. This can have serious implications on justice delivery. A records management programme must provide for suitable storage and security for records to ensure effective management and timeous accessibility (Iwhiwhu 2005). 
Storage and security of records are important to guard against misplacement and loss of records, which is a perennial problem in many recordkeeping systems (Mafu 2014; Maseh 2015; Ngoepe \& Makhubela 2015). Misplaced, missing or lost court records compromise the promotion of administration of justice. Maseh (2015) states that courts in Kenya often face challenges such as backlogs of cases, lost, misfiled or damaged files, delays in registering cases, locating records and filing documentation. According to responses from the Alice Magistrates' Court, four out of seven (57\%) respondents indicated that they had experienced challenges of missing or misplaced. The researcher sought clarification from the court manager during the interview. According to the court manager:

"When the perpetrator is brought to court, the clerks are requested to bring all the relevant information as evidence against the perpetrator, including the previous records if the person is not committing the crime for the first time. So now, if the documents are missing in the case of physical part, there are complaints and it becomes the challenge in decision making, because the temporary file does not sometimes contain everything about the person, as a result, at times the perpetrator has to be set free because the evidence has been lost."

Human capital is essential for records management for justice delivery. Managing records for justice delivery needs professionally trained records managers, formal training and training materials in judicial records and information management, and having expert advice and guidance available to those with responsibility for records and information management in courts (Saman \& Haider 2012). Respondents in the Alice Magistrates' Court held different academic and professional training qualifications. The majority (four out of seven (57\%)) of the respondents had attained a diploma as their highest qualification, two out of seven (29\%) a matric certificate, while one out of seven (14\%) had a degree (Figure 1 and Table 1). This gives the impression that although the majority (five out of seven) had either a diploma or degree, they lacked the necessary professional knowledge and skills for managing records. Similarly, Muchaonyerwa and Khayundi (2014) reported that the majority of the respondents managing electronic records at the Office of the Premier of Eastern Cape Province had degrees but were not familiar with records management principles, standards, and legislative and statutory requirements for managing records.

This is contrary to the legislative and statutory requirements for records management programmes in government departments. According to the National Archives and Records Service, those responsible for records management should have a relevant national diploma or a bachelor's degree in information management and/or records management. In addition, staff managing records should undergo continuous in-house and external training to enhance knowledge and skills in areas such as knowledge management, document management, and electronic records management. This seems to point to the weak records management programmes in government departments (Ngoepe 2016). Weak court records management programmes undermine justice delivery as managing records is left to those without knowledge and skills to guarantee efficient and effective management of records for justice delivery (Motsaathebe \& Mnjama 2009; Ngoepe \& Makhubela 2015). 


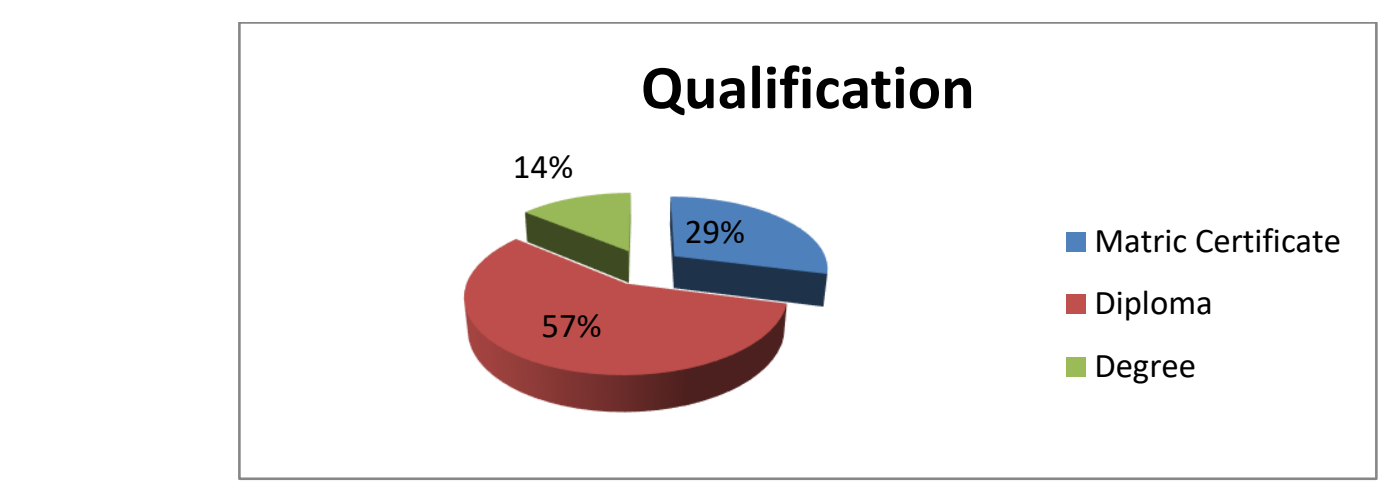

Figure 1: Qualification of the court staff in AMC Source: Field data 2017

\section{Table 1: Types of training}

\begin{tabular}{|l|l|l|}
\hline Types of training & Frequency & Percentage of respondents (\%) \\
\hline Short courses & 0 & 0 \\
\hline Workshop & 3 & 50 \\
\hline Professional training & 0 & 0 \\
\hline $\begin{array}{l}\text { Other (please specify): } \\
\text { Professional courses }\end{array}$ & 2 & 33 \\
\hline Do not remember & 1 & 17 \\
\hline Total & 6 & 100 \\
\hline
\end{tabular}

\section{Source: Field data 2017}

Furthermore, although the majority (six out of seven (86\%)), of the respondents indicated to have attended training, none of them had professional training in records management (Table 1). This is contrary to the requirements that staff who manage records as well as other staff not involved in records management must attend appropriate professional training to equip them with knowledge and skills for effective and efficient management and use of records. Many education and training programmes for managing records and archives are available in the country. Moreover, a course for staff involved in managing of records and archives is offered at the National Archives in Pretoria (Government of South Africa 2007). This finding portrays a weak records management programme at the Alice Magistrates' Court.

\subsection{Records in justice delivery by courts}

The DOJ\&CD's vision is a transformed and accessible justice system that promotes and protects social justice and rule of law. The mission is, among others, to facilitate the (effective and efficient) resolution of criminal, civil, and family law disputes by providing accessible, efficient, and quality administrative support to courts, and effectively and cost-efficiently provide legal services that anticipate, meet, and exceed stakeholder needs and expectations (Government of South Africa 2021). This has implications for efficient management of court records. In court processes, judges, registrars, litigation officers and other court personnel need records in the execution of various judicial and court processes (Huni \& Dewah 2019). Section 210 of the South African Criminal Procedure requires that "no evidence as to any fact, matter 
or thing shall be admissible which is irrelevant or immaterial and which cannot conduce to prove or disprove any point of fact at issue in criminal proceedings." Furthermore, section 35(5) of the Constitution of the Republic of South Africa (Act No.8 of 1996) as amended in 2003, states that "evidence obtained in a manner that violates any right in the Bill of Rights must be excluded if the admission of that evidence would render the trial unfair or otherwise be detrimental to the administration of justice" (Government of South Africa 1996).

Most of the respondents underscored the importance of records in the court processes in the Alice Magistrates' Court. Five out of seven (71\%) respondents indicated retrieval of documents relevant to any case prior to the time of each court hearing. Apparently, this is a global practice (Anderson, Dodd \& Roos 2012; Criminal Practice Directives 2017; Meintjes-Van der Walt et al. 2011; Schmallenger 2014). This underscores the significance of court records in justice delivery. Lost, misplaced, or stolen files deny courts the necessary evidence to deliver justice in time or at all (Abioye 2014; Dewah \& Mutula 2016; Huni \& Dewah 2019; Mafu 2014; Maseh 2015; Namakula 2016; Ngoepe \& Makhubela 2015). The mass media more often report of cases of justice delayed or denied due to a lack of evidence in the form of missing or lost dockets (Ngoepe \& Makhubela 2015; Samodien 2013).

The court manager confirmed this during the interview with the researcher. As the administrative head of the court, the manager explained that before any case is due for hearing, clerks were required to retrieve all relevant records including records of complainant, defendant, witnesses, and any other records relevant to the case. In the words of the manager: "If someone is arrested in Alice for theft or ordinary theft, house breaking with intents to steal. That very same person was arrested probably in Fort Beaufort or in King William's Town, now when the case is decided, there should be proof of previous convictions so the EEM, the crime statistics in Pretoria and in Cape Town, once finger prints are taken, so it shows that this person is a habitual criminal in cases of theft, house breaking with intend to steal or whatever, so all those things they help us ... this helps the judge or magistrate in making decision about the case brought before court. This is important since it enables the judge or magistrate to make informed decisions."

Furthermore, the court manager explained that records are important in determining the duration of sentence. Those with previous offences are not likely to receive the same sentence as first offenders. In other words, records help judges and magistrates make informed decisions about each court case. In his words, the manager stated that:

"There is this thing what they call a charge sheet when one has been arrested, yeah in fact, it starts with the police, the police open a docket, the investigator collects all the relevant information as evidence against the perpetrator or the person who has been arrested. He is been brought to court, so when the judge or magistrate is about to give judgement on that particular case. Previous convictions need to be headed in court, so those previous records zalomntu zikwi Archives (literally means for that person in archives), so they retrieve all those previous records. So for the purposes of sentence ukuba (literally means if) this person is not the first offender as the attorney probably may say mitigation of sentence. So they find out no this one is the habitual criminal, so the sentence izabankulu (literally means will be big)." 


\subsection{Challenges in courts records management}

The researcher was keen to know the challenges facing records management for justice delivery at the Alice Magistrates' Court. Four out of seven (57\%) of the respondents indicated misplaced files. Misplacement was mainly due to misfiling of records, especially after use. Misplaced and lost files are the major causes of the case delays or subversion of justice delivery by courts. If records are not available, a court cannot proceed with the justice delivery processes (Ngoepe \& Makhubela 2015; Motsaathebe \& Mnjama 2009). When asked how they deal with the problem of missing or lost records or files, most of the respondents mentioned creation of temporary files, which was confirmed by the manager. The use of temporary records for justice poses challenges of authenticity, integrity, and admissibility. In addition, it implies a weak infrastructure, and a lack of necessary skills and knowledge for records management (Lowry 2012; Ngoepe \& Makhubela 2015). This situation is becoming worse due to the rapid accumulation of records in electronic format. It is possible that covid-19 will lead to increased adoption of virtual justice delivery court systems.

The Department of Justice and Constitutional Development has a master plan for e-judicial system, but it seems the rollout of electronic records management systems is slow, especially in the lower courts (Saurombe 2014). The researcher wanted to know the challenges the court experienced in managing electronic records for justice delivery. Seven out of seven $(100 \%)$ respondents indicated a lack of equipment for managing the electronic records. The respondents also indicated that if there was load shedding, there was no back-up electricity supply; therefore, it was difficult to access the records on computers at such times and this may cause delays in justice delivery by the court.

\section{Conclusions and recommendations}

The findings of the study revealed that although records are important for justice delivery at the Alice Magistrates' Court, the existing records management programme is not efficient and effective and does not sufficiently comply with the legislative and statutory requirements. A lack of sufficient infrastructure and the necessary human capital are major challenges to records management for justice delivery. Based on these findings, the study recommends that Alice Magistrates' Court needs to enhance its existing records management programme for justice delivery by implementing the following:

- Enhance compliance with the legislative and statutory requirements for efficient and effective records management for justice delivery.

- Implement an e-justice system for electronic records management based on national and international standards for timeous justice delivery and expansion of virtual justice delivery in view of the covid-19 pandemic.

- Facilitate professional training for all staff, including attendance of seminars, workshops, and workplace training.

- Develop adequate capacity for infrastructure and human resources for court records management. 


\section{References}

Abioye, A. 2014. Court records management and efficient administration of justice in Nigeria. African Journal of Library, Archives and Information Science 24(1): 27-39.

Ambira, C.M., Kemoni, H.N. \& Ngulube, P. 2019. A framework for electronic records management in support of e-government in Kenya. Records Management Journal, 29(3): 305-319.

Anderson, A.M., Dodd, A. \& Roos, M.C. 2012. Everyone's guide to South African Law. 3rd ed. Cape Town: Zebra Press.

Barroca, M. 2014. Records classification system and retention schedule: Customized 2012 LGMA System for the District of Sparwood. Sparwood.

Caughey, M. 2004. Keeping attorney from trashing identities: malpractice as backstop protection for clients under the United States Judicial Conference's Policy on electronic court records. Washington Law Review 79(1): 407-436.

Dewah, P. \& Mutula, S. 2016. The nexus between legal records and human rights in the justice delivery system: the case of Bulawayo Magistrates' Courts, Zimbabwe. Information Development 32(5): 1513-1527.

Government of South Africa. 1996. Constitution of the Republic of South Africa No. 108 of 1996, second amendment No. 3 of 2003. Pretoria: Government Press. Available at: https://www.gov.za>a108-96.pdf (accessed 25 April 2021).

Government of South Africa. 2007. National Archives and Records Service of South Africa: Records management policy manual. Pretoria: Government Press. Available at: https://www.national.archives.gov.za (accessed 14 May 2020).

Government of South Africa. 2021. Department of Justice: Department of Justice and Constitutional Development. Pretoria: Government Press. Available at https://www.justice.gov.za (accessed 29 April 2021).

Huni, P. \& Dewah, P. 2019. Admissibility of digital records as evidence in Bulawayo High Court in Zimbabwe. Journal of the South African Society of Archivists, 52: 133-148.

International Records Management Trust and World Bank. 2002. Evidence-based governance in the Electronic Age: case study of legal and judicial records and information systems in South Africa. Washington: A World Bank/International Records Management Trust Partnership Project.

International Standard Organization (ISO) 15489-1. 2016. Information and documentationrecords management: concepts and principles. 2nd ed. Switzerland: ISO.

Iwhiwhu, E.B. 2005. Management of records in Nigerian Universities: problems and prospects. The Electronic Library 23(3): 345-355.

Judicial system of South African Government. 2021. Government of South Africa. Available at https://www.gov.za>judicial-system (accessed 25 April 2021).

Kilgour, L. 2013. Tracing the lifecycle of Canadian criminal records: an examination in relation to public policy and use access and comprehension. Records Management Journal 23(2): 136-148.

Leedy, P.D. \& Ormrod, J.E. 2010. Practical researcher: planning and design. New Jersey: Merrill Prentice hall.

Lowry, J. 2013. Correlations between ICT and records policy integration and court case management system functionality: East African case studies. Records Management Journal 23(1): 51-60. 
Luyombya, D. \& Sennabulya, S. 2012. An analysis of the public archives infrastructure in Uganda. Comma: International journal on archives 2012 (1): 67-78.

Mafu, N.V. 2014. The management of court records in magistrate court: a case of Middledrift Magistrate Court, Eastern Cape. Master's Dissertation, University of Fort Hare.

Maseh, E. 2015. Managing court records in Kenya. African Journal of Library, Archives and Information Science 25(1): 77-87.

Meintjes-Van der Walt, L., Singh, P., Du Preez, M., De Freitas, S.A., Chinnian, K., Barratt, A., Govindjee, A., Iya, P., De Bruin, J.H. and Van Coller, H.P. 2011. Introduction to South African Law: fresh perspectives. 2nd ed. Cape Town: Heinemann.

Mosweu, T.L. \& Kenosi, L. 2018.Implementation of the court records management system in the delivery of justice at the Gaborone Magisterial District, Botswana. Records management Journal DOI: https://doi.org/10.1108/RMJ-11-2017-0033.

Motsaathebe, L. \& Mnjama, N. 2009. The management of high court records in Botswana. Records Management Journal 19(3): 173-189.

Muchaonyerwa, N. * Khayundi, F. 2014. The management of digital records in the Office of the Premier of the Eastern Cape Province, South Africa. African Journal of Library, Archives and Information Science 24(1): 41-52.

Namakula, C.S. 2016. The court records and the right to a fair trial: Botswana and Uganda. African Human Rights Law Journal 175-203.

Ngoepe, M. 2016. Records management models in the public sector in South Africa: is there a flicker of light at the end of the dark tunnel? Information Development 32(3): 338-353.

Ngoepe, M. \& Makhubela, S. 2015. Justice delayed is justice denied: records management and the travesty of justice in South Africa. Records Management Journal 25(3): 288-305.

Ngoepe, M., Mokoena, L. \& Ngulube, P. 2010. Security, privacy and ethics in electronic records management in the South African public sector. ESARBICA Journal 29: 36-66.

Ntengenyane, K. 2018. The management of court records for justice delivery: a case study of Alice Magistrate Court in the Eastern Cape, South Africa. Master's Dissertation, University of Fort Hare.

Raaen, N. 2014. Order in the courts! RM principles for the judiciary. Information Management Journal 48(1): 28-32.

Saman, W.S. \& Haider, A. 2012. Electronic court records management: a case study. Journal of e-Government studies and Best Practices 1-11.

Samodien, L. 2013. Missing court records bedevil cases on appeal. Cape Times: SA-Media University of the Free State.

Saurombe, A. 2014. Towards the adoption of e-justice in South Africa and the developing world: prospects and challenges. ESARBICA Journal 33: 83-95

Schmallenger, F. 2014. Criminal justice today: an introductory text for the $21^{\text {st }}$ Century. 10th ed. Upper Saddle River: Prentice Hall.

Sindane, N. 2013. A transforming justice system. Department of Justice and Constitutional Development: CEO. Available at www.justice.gov.za/docs/articles/201311-dg-ceotransforming-justice.pdf (accessed 06 April 2018).

South African Law Commission. 2002. Conviction rates and other outcomes of crime reported in eight South African police areas. Available at: www.justice.gov.za/salrc/rpapers/rp18.pdf (accessed 07 April 2017).

Spratt, C. 2007. Electronic access to court records. News Media and the Law. Reporters Committee for Freedom of the Press, HighBeam Research. Available at: http://www.highbeam.com/doc/IP3-1304397411.html (accessed 12 June 2017). 